\title{
Is Fish Domestication Going Too Fast?
}

\author{
Fabrice Teletchea \\ Research Unit Animal and Functionalities of Animal Products (URAFPA), University of Lorraine, Nancy, France \\ Email: fabrice.teletchea@univ-lorraine.fr
}

Received 1 June 2016; accepted 25 June 2016; published 28 June 2016

Copyright (C) 2016 by author and Scientific Research Publishing Inc.

This work is licensed under the Creative Commons Attribution International License (CC BY). http://creativecommons.org/licenses/by/4.0/

(c) (7) Open Access

\begin{abstract}
Domestication is a very strong process that has enabled humans to produce both plants and animals with desired traits. For land animals, this process started about 12,000 years ago and resulted in that today hundreds of well-defined breeds are available for the five most important farmed mammal species (cattle, pig, horse, sheep and goat). For aquatic animals, this process started much earlier, and the bulk of domestication of new species dated back only to the early 1980s. Nevertheless, there are now numerous fish species for which the life cycle is already closed in captivity and some domesticated fish have been genetically improved. This implies that what probably took hundreds of years in mammals (i.e., to control the life cycle in captivity and then to improve captive individuals) has been accomplished in only tens of years for some fish species. Based on the main problems observed today in farmed mammals, the possible consequences of this fast domestication of fish are discussed.
\end{abstract}

\section{Keywords}

Domestication, Farmed Animals, Mammals, Fish, Global Change

\section{Introduction}

Domestication is, by definition, a long and endless process during which animals become progressively adapted to both captive conditions and humans [1]-[5]. This process implies first to control part of the life cycle of the targeted species in captivity [1] [3]. Then, once the entire life cycle is closed in captivity, the process can proceed further up to the establishment of well-defined breeds displaying specific traits [2] [4].

In order to better describe the diversity of farm practices applied today, particularly in aquaculture, Teletchea and Fontaine [6] have recently proposed a new classification with five levels of domestication. The first level corresponds to the initial trials of acclimatization of wild animals to captive environment. In other words, as soon as wild animals are transferred to captivity, domestication starts. Nevertheless, if the process stops at this level, it corresponds only to taming, i.e., to the modification of behavior of a wild animal during its lifetime; yet no genetic modification will be transmitted to the offspring [1]. Then, once part of the life cycle is controlled in 
captivity, the level 2 is reached. Major bottlenecks have to be overcome in order to close the life cycle in captivity, among which the most important is breeding in captivity [6]. Then, once the entire life cycle is controlled, but there are still wild inputs into the captive stocks, the level 3 is reached. The level 4 also implies that the entire life cycle is closed in captivity, but wild animals are no longer brought into the captive stocks. Most authors would probably consider that at the level 4 , captive animals are domesticated, particularly when they sufficiently differ from their wild congeners [4]-[6]. The level 5 is reached when specific breeding programs have been developed to improve one or several traits, which results in well-defined breeds [6]. Importantly, reaching any level does not necessarily imply that the entire species is at that level; different populations (or groups of individuals) within the same species can indeed display different domestication levels, even within the same geographic area or in a given farm [6].

Within the framework of this new classification, the first goal of the present study is to briefly describe the history of domestication of land animals and then assess the main problems encountered today in the five major farmed species. Then, the second goal is to summarize the history of fish domestication and discuss whether it is too fast compared to land animals.

\section{Domestication of Land Animals: What Consequences?}

\subsection{Brief History of Domestication of Land Animals}

In land, domestication started about 12,000 years ago for the five main farmed mammal species that represents today the bulk of what we eat: cow (Bostaurus and B. indicus), sheep (Ovisaries), goat (Capra hircus), pig (Sus scrofa) and horse (Equus caballus) [7]-[11]. Domestication was acrucial step in human history, known as the Neolithic transition, which results in a progressive shift from hunting-gathering to farming, and eventually inhuman population explosion that has continued unabated to this day [7] [9] [11].

Following the seminal research of Darwin, strongly influenced by European animal breeding practices during the $19^{\text {th }}$ century, domestication studies have most often emphasized the crucial role of humans by focusing on genetic isolation of captive animals from wild congeners and directed or controlled breeding of individuals [12], which corresponds to the domestication level 4 and 5, respectively. Therefore, it was generally considered that the creation of separate breeding populations of animals completely isolated from their wild progenitors was essential for domestication [12] [13]. Besides, it was assumed that domestication occurred only once at a specific place for each domesticated species and involved a strong population bottleneck that significantly reduced genetic diversity [14].

New archeological, genetic and ethnohistorical findings suggest, however, that exchanges between wild and captive/domestic animals were frequent in the earliest phase of domestication and probably lasted several centuries [12]. This implies that complete separation between wild and captive populations was relatively late and region-specific [12]. According to Teletchea and Fontaine's classification [6], this means that currently domestic animals remained at the domestication levels 2 to 3 for a very long period of time, and only reached the level 4 quite recently (variable according to species and breeds). This is particularly true for animals used for transport, such as donkey (Equusasinus), horse or Bactrian camel (Camelusbactrianus) [12]. Yet, this also might be the case for other domesticated species, including animals kept for meat and secondary products, such as milk or wool [12]. There is, indeed, strong evidence for gene flow for a long period of time between pig, sheep, goat, and cattle, and their wild relative in areas of common distribution [12].

\subsection{Evolution of Genetic Diversity during Animal Domestication}

A common misconception about domestic animals is that they are highly inbred [14] [15]. This might be true only if one considers certain breeds, but as a whole, domestic species are characterized by a high degree of genetic diversity [14] [15]. This is chiefly due to the fact that effective population size $\left(N_{e}\right)$, which is estimated on the basis of the size of both the female and the male breeding populations [16], were large during most part of the domestication process [15], for reasons explained above.

However, particularly when breed formation started in the mid-18 ${ }^{\text {th }}$ century [17], followed by the application of modern breeding methods, such as artificial insemination, in the past decades, $N_{e}$ declined, resulting in strong genetic bottlenecks in certain breeds [15] [18]. For instance, estimates of current $N_{e}$ in several commercial taurine cattle breeds are now very low $(\leq 150)$ and those breeds generally display low genetic variability [15]. One extreme case is a feral British breed, Chillingham cattle, in which 24 out of 25 microsatellites loci were found to 
be homozygous [15]. Nevertheless, genetic isolation was rarely absolute for most breeds, and gene flow did not stop, even after when cattle [19] or sheep [20] were partitioned into breeds. For cattle, the history of breeds, indeed, mentions deliberate upgrading in order to improve production characteristics by using bulls of other populations from the same or a different country [19].

In the past decades, highly productive breeds (e.g., Holstein-Friesian for dairy cattle [17]) have progressively replaced or crossbred local breeds (present in only one country) to the point that they have effectively disappeared [16] [17] [21] [22]. According to the FAO, one-fifth of the 7600 breeds reported worldwide, belonging to 34 mammalian and avian species, are at risk, and 62 breeds already became extinct in the past years [16]. However, growing concerns about the erosion of genetic resources of farm animals and general skepticism regarding the side effects of technological progress, have promoted initiatives to conserve local breeds [17] [21] [22]. These local breeds, which have often developed adaptations to local, sometimes extreme conditions, belong to our cultural heritage and are of local cultural importance, even if most are only one or two centuries old [17].

\subsection{Main Negative Effects of Domestication/Selection}

In last decades, genetic selection has considerably increased production performances of farmed species [23] [24]. However, in the meantime, negative side effects have become more apparent [23] [24]. Animals that have been genetically selected for high production efficiency could also present some undesirable side effects for several reproduction, health and metabolic traits (Table 1). For instance, after less than a century of animal breeding, the double muscling phenotype (a trait selected for meat production), which is nearly fixed in Belgian Blue cattle, also results in that calves are now delivered by caesarean section [15].

Therefore, the goals of breeding programs have to be redefined including not only production traits, but also economical traits, such as veterinary costs (e.g., resulting from higher diseases), as well as the welfare of animals, which is becoming an important issue, particularly in European countries [23] [24].

\section{Domestication of Fish Species}

\subsection{Brief History of Fish Domestication}

Compared to land animals, the domestication of fish species is much more recent [6] [25] [26]. Except for few species, among which common carp (Cyprinus carpio) and Nile tilapia (Oreochromis niloticus), the bulk of domestication trials dated back to the early 1980s [6] [25] [27]. Nevertheless, several species have already reached the level 5 [28]-[31], even though globally less than $10 \%$ of the aquaculture production comes from selectively bred farm stocks [28] [29]. A survey on the selective breeding programmes developed in European countries is provided in Table 2. One of the best examples of rapid domestication is the Atlantic salmon (Salmo salar), whose first trials (level 1) started in the early 1970s in Norway [28] [32]. Less than four decades later, almost $100 \%$ of all farmed salmon worldwide have reached the level 5 , and are sourced from a relatively small number of companies that utilize the original Norwegian fish, or a mixture of local and imported strains in Scotland, Chile and Iceland [28].

Table 1. Possible negative side effects of selection for high production efficiency in two farmed species (adapted from [23] [24]).

\begin{tabular}{|c|c|c|c|c|}
\hline \multirow{2}{*}{ Species } & \multirow{2}{*}{ Breeding goals } & \multicolumn{3}{|c|}{ Possible negative side effects of selection } \\
\hline & & Reproduction & Health & Metabolism \\
\hline Pig & $\begin{array}{l}\text { High growth rate } \\
\text { and/or minimum } \\
\text { back fat thickness }\end{array}$ & $\begin{array}{c}\text { Prolonged interval from weaning to farrowing } \\
\text { Delayed onset of puberty } \\
\text { Shorter pro-oestrus } \\
\text { More frequent vulvar symptoms }\end{array}$ & More leg weakness & \\
\hline Dairy cattle & High milk yield & $\begin{array}{c}\text { Breeding later } \\
\text { Longer calving interval } \\
\text { Higher number of inseminations per } \\
\text { conception }\end{array}$ & $\begin{array}{c}\text { More digestive disorders } \\
\text { More skin or skeletal disorders } \\
\text { More udder edema } \\
\text { Higher risk of mastitis }\end{array}$ & $\begin{array}{l}\text { Lower energy balance } \\
\text { Loss of body condition } \\
\text { score }\end{array}$ \\
\hline
\end{tabular}


Table 2. Survey of European fish species that have reached the level 5, classified according to their global aquaculture production in 2014 (from [28] [31]). Importantly, this does not imply that the entire production is based on improved stocks [31], particularly for common carp. Generations: number of generations under selection in the oldest breeding program (if known).

\begin{tabular}{cccc}
\hline Species & Common name & Generations & Production (tons) \\
\hline Solea solea & Common sole & & 88 \\
Gadus morhua & Atlantic cod & $>3$ & 1696 \\
Salmo trutta & Sea trout & & 4389 \\
Argyrosomus regius & Meagre & 5 & 11,770 \\
Scophthalmus maximus & Turbot & 8 & 71,851 \\
Dicentrarchus labrax & European seabass & 7 & 156,450 \\
Sparus aurata & Gilthead seabream & 14 & 158,389 \\
Oncorhynchus mykiss & Rainbow trout & 11 & 812,940 \\
Salmo salar & Atlantic salmon & & $2,326,288$ \\
Cyprinus carpio & Common carp & $4,159,177$ \\
\hline
\end{tabular}

\subsection{Selective Breeding Programs in Fish: Which Goals?}

Selective breeding programs in fish have most often focused on improving growth rate [33]-[35]. The genetic gain averaged about $10 \%$ - 14\% per generation, which is about four to five-fold greater than what is usually obtained in breeding programs for land species [33] [34]. This is mainly due to: a higher genetic variance in fish compared to farm animals, the high fecundity of fish allows for higher selection intensity than in farm animals, and selection has just started in fish, thus problems with reallocation of limited resources has not yet occurred [35]. Other traits have also been included more recently in some breeding programs, such as disease resistance, feed conversion ratio, or flesh quality [33] [34]. However, it was found that without proper management, numerous breeding programs resulted in a rapid loss of genetic diversity as a consequence of inbreeding, leading to a decline of productivity and ultimately the abandon of the program [29] [34] [36]. As most farmed fish species are at an early stage of domestication (levels 2 or 3) or selection (levels 5, but only a few generations), precautions should, therefore, be taken to avoid inbreeding as well as the apparition of similar undesirable side effects (e.g., reduced reproductive performance [28]), as described above for certain livestock breeds [34]. This requires that breeding programs include not only market (e.g., growth rate, flesh quality), but also non-market values (e.g., ethical, welfare), as well as reproductive traits (e.g., fecundity, egg/larvae quality traits) [28] [35]. Also, the size of $N_{\mathrm{e}}$ should be sufficiently large and genetically diverse when starting and then running a breeding program [29] [35]. At last, it is important to consider the possible introduction of genetic variability from outside the breeding stock (wild fish or domesticated fish from other farms [29]) to avoid as much as possible long-term inbreeding and loss of genetic variability [35]. This will probably affect performance, but will help increasing or maintaining the genetic variability on the long term [36].

\section{Conclusion}

Domestication is a very strong process that has allowed humans to produce various domesticated plants and animals with a large range of desired traits. In land, domestication started about 12,000 years ago and captive animals remained at the levels 2 or 3 for a very long period of time. Thereafter, during the past centuries, domesticated animals reached the levels 4 and then 5 when breeds were created. This results in that today, domesticated animals display a high genetic variability, and strong negative side effects of domestication are restricted to some highly inbred breeds. For aquatic animals, the domestication is much more recent, and the time required to evolve from level 1 to level 5 could be as short as one or two decades in some species. Therefore, what took probably hundreds of years in mammals, took only few years in some fish species. This might result in a strong decrease of the genetic variability of domesticated stocks, particularly when compared to their wild congeners, and ultimately to the apparition of some negative side effects much quicker than in mammals. Therefore, caution 
should be taken when implementing breeding programs to adequately balance the demand for improving rapidly fish production performances and the conservation of sufficient genetic variability and capacity of fish to adapt to diverse environment, particularly in the current context of climate change.

\section{Acknowledgements}

The author thanks one anonymous reviewer for comments on an earlier draft.

\section{References}

[1] Price, E.O. (1999) Behavioral Development in Animals Undergoing Domestication. Applied Animal Behavior Science 65, 245-271. http://dx.doi.org/10.1016/S0168-1591(99)00087-8

[2] Mignon-Grasteau, S., Boissy, A., Bouix, J., Faure, J.-M., Fisher, A.D., Hinch, G.N., Jensen, P., Le Neindre, P., Mormède, P., Prunet, P., Vandeputte, M. and Beaumont, C. (2005) Genetics of Adaptation and Domestication in Livestock. Livestock Production Science, 93, 3-14. http://dx.doi.org/10.1016/j.livprodsci.2004.11.001

[3] Mirkena, T., Duguma, G., Haile, A., Tibbo, M., Okeyo, A.M., Wurzinger, M. and Sölkner, J. (2010) Genetics of Adaptation in Domestic Farm Animals: A Review. Livestock Science, 132, 1-12. http://dx.doi.org/10.1016/j.livsci.2010.05.003

[4] Larson, G. and Burger, J. (2013) A Population Genetics View of Animal Domestication. Trends in Genetics, 29, 197205. http://dx.doi.org/10.1016/j.tig.2013.01.003

[5] Zeder, M.A. (2015) Core Questions in Domestication Research. Proceedings of the National Academy of Sciences of the United States of America, 112, 3191-3198. http://dx.doi.org/10.1073/pnas.1501711112

[6] Teletchea, F. and Fontaine, P. (2014) Levels of Domestication in Fish: Implications for the Sustainable Future of Aquaculture. Fish and Fisheries, 15, 181-195. http://dx.doi.org/10.1111/faf.12006

[7] Diamond, J. (2002) Evolution, Consequences and Future of Plant and Animal Domestication. Nature, 418, $700-707$. http://dx.doi.org/10.1038/nature01019

[8] Tresset, A. and Vigne, J.-D. (2011) Last Hunter-Gathers and First Farmers of Europe. Comptes Rendus Biologies, 334, 182-189. http://dx.doi.org/10.1016/j.crvi.2010.12.010

[9] Vigne, J.-D. (2011) The Origins of Animal Domestication and Husbandry: A Major Change in the History of Humanity and the Biosphere. Comptes Rendus Biologies, 334, 171-181. http://dx.doi.org/10.1016/j.crvi.2010.12.009

[10] Larson, G., Piperno, D.R., Allaby, R.G., Purugganan, M.D., Andersson, L., Arroyo-Kalin, M., Barton, L., Climer Vigueira, C., Denham, T., Dobney, K., Doust, A.N., Gepts, P., Gilbert, M.T.P., Gremillion, K.J., Lucas, L., Lukens, L., Marshall, F.B., Olsen, K.M., Pires, J.C., Richerson, P.J., Rubio de Casas, R., Sanjur, O.I., Thomas, M.G. and Fuller, D.Q. (2014) Current Perspectives and the Future of Domestication Studies. Proceedings of the National Academy of Sciences of the United States of America, 111, 6139-6146. http://dx.doi.org/10.1073/pnas.1323964111

[11] Vigne, J.-D. (2015) Early Domestication and Farming: What Should We Know or Do for a Better Understanding? Anthropozoologica, 50, 123-150. http://dx.doi.org/10.5252/az2015n2a5

[12] Marshall, F.B., Dobney, K., Denham, T. and Capriles, J.M. (2014) Evaluating the Roles of Directed Breeding in Gene Flow in Animal Domestication. Proceedings of the National Academy of Sciences of the United States of America, 111, 6153-6158. http://dx.doi.org/10.1073/pnas.1312984110

[13] Driscoll, C.A., Macdonald, D.W. and O’Brien, J. (2009) From Wild Animals to Domestic Pets, an Evolutionary View of Domestication. Proceedings of the National Academy of Sciences of the United States of America, 106, 9971-9978. http://dx.doi.org/10.1073/pnas.0901586106

[14] Andersson, L. (2012) Genetics of Animal Domestication. In: Gepts, P., Famula, T.R., Bettinger, R.L., Brush, S.B., Damania, A.B., McGuire, P.E. and Qualset, C.O., Eds., Biodiversity in Agriculture, Domestication, Evolution, and Sustainability, Cambridge University Press, Cambridge, 260-274. http://dx.doi.org/10.1017/cbo9781139019514.014

[15] Wiener, P. and Wilkison, S. (2011) Deciphering the Genetic Basis of Animal Domestication. Proceedings of the Royal Society B-Biological Sciences, 278, 3161-3170. http://dx.doi.org/10.1098/rspb.2011.1376

[16] Groeneveld, L.F., Lenstra, J.A., Eding, H., Toro, M.A., Scherf, B., Pilling, D., Negrini, R., Finlay, E.K., Jianlin, H., Groeneveld, E., Weigend, S. and The GLOBALDIV Consortium (2010) Genetic Diversity in Farm Animals-A Review. Animal Genetics, 41, 6-31. http://dx.doi.org/10.1111/j.1365-2052.2010.02038.x

[17] Felius, M., Beerling, M.L., Buchana, D.S., Theunissen, B., Koolmees, P.A. and Lenstra, J.A. (2014) On the History of Cattle Genetic Resources. Diversity, 6, 705-750. http://dx.doi.org/10.3390/d6040705

[18] De Roos, A.P.W., Hayes, B.J., Spelman, R.J. and Goddard, M.E. (2008) Linkage Disequilibrium and Persistence of Phase in Holstein-Friesian, Jersey and Angus Cattle. Genetics, 179, 1503-1512. 
http://dx.doi.org/10.1534/genetics.107.084301

[19] Felius, M., Koolmees, P.A., Theunissen, B., Lenstra, J.A. and European Cattle Genetic Diversity Consortium (2011) On the Breeds of Cattle-Historic and Current Classifications. Diversity, 3, 660-692. http://dx.doi.org/10.3390/d3040660

[20] Kijas, J.W., Lenstra, J.A., Hayes, B., et al. (2012) Genome-Wide Analysis of the World’s Sheep Breeds Reveals High Levels of Historic Mixture and Strong Recent Selection. PLoS Biology, 10, e1001258. http://dx.doi.org/10.1371/journal.pbio.1001258

[21] Taberlet, P., Valentini, A., Rezaei, H.R., Naderi, S., Pompanon, F., Negrini, R. and Ajmone-Marsan, P. (2008) Are Cattle, Sheep, and Goats Endangered Species? Molecular Ecology, 17, 275-284. http://dx.doi.org/10.1111/j.1365-294X.2007.03475.x

[22] Taberlet, P., Coissac, E., Pansu, J. and Pompanon, F. (2011) Conservation Genetics of Cattle, Sheep and Goats. Comptes Rendus Biologies, 334, 247-254. http://dx.doi.org/10.1016/j.crvi.2010.12.007

[23] Rauw, W.M., Kanis, E., Noordhuizen-Stassen, E.N. and Grommers, F.J. (1998) Undesirable Side Effects of Selection for High Production in Farm Animals: A Review. Livestock Production Science, 56, 15-33. http://dx.doi.org/10.1016/S0301-6226(98)00147-X

[24] Oltenacu, P.A. and Algers, B. (2005) Selection for Increased Production and the Welfare of Dairy Cows: Are New Breeding Goals Needed? Ambio, 34, 311-315. http://dx.doi.org/10.1579/0044-7447-34.4.311

[25] Teletchea, F. (2012) Qu'est-ce qu'un Poisson Domestique? Implications pour le Développement Futur de l’Aquaculture. Ethnozootechnie, 90, 7-12.

[26] Teletchea, F. (2015) Domestication and Genetics: What a Comparison between Land and Aquatic Species Can Bring? In: Pontarotti, P., Ed., Evolutionary Biology: Biodiversification from Genotype to Phenotype, Chapter 20, Springer, Berlin, 389-401. http://dx.doi.org/10.1007/978-3-319-19932-0_20

[27] Balon, E.K. (2004) About the Oldest Domesticates among Fishes. Journal of Fish Biology, 65, 1-27. http://dx.doi.org/10.1111/j.0022-1112.2004.00563.x

[28] Migaud, H., Bell, G., Cabrita, E., McAndrew, B., Davie, A., Bobe, J., Herráez, M.P. and Carillo, M. (2013) Gamete Quality and Broodstock Management in Temperate Fish. Reviews in Aquaculture, 5, S194-S223. http://dx.doi.org/10.1111/raq.12025

[29] Olesen, I., Bentsen, H.B., Phillips, M. and Ponzoni, R.W. (2015) Can the Global Adoption of Genetically Improved Farmed Fish Increase beyond 10\%, and How? Journal of Marine Science and Engineering, 3, 240-266. http://dx.doi.org/10.3390/jmse3020240

[30] Teletchea, F. (2015) Domestication of Marine Species: Update and Perspectives. Journal of Marine Science and Engineering, 3, 1227-1243. http://dx.doi.org/10.3390/jmse3041227

[31] Chavanne, H., Janssen, K., Hofherr, J., Contini, F., Haffray, P., Komen, H., Nielsen, E.E., Bargelloni, L. and Aquatrace Consortium (2016) A Comprehensive Survey on Selective Breeding Programs and Seed Market in the European Aquaculture Fish Industry. Aquaculture International, 1-21.

[32] Gjedrem, T. (2010) The First Family-Based Breeding Program in Aquaculture. Reviews in Aquaculture, 2, 2-15. http://dx.doi.org/10.1111/j.1753-5131.2010.01011.x

[33] Gjedrem, T., Robinson, N. and Rye, M. (2012) The Importance of Selective Breeding in Aquaculture to Meet Future Demands for Animal Protein: A Review. Aquaculture, 350-353, 117-129.

http://dx.doi.org/10.1016/j.aquaculture.2012.04.008

[34] Nguyen, N.H. (2016) Genetic Improvement for Important Farmed Aquaculture Species with a Reference to Carp, Tilapia and Prawns in Asia: Achievements, Lessons and Challenges. Fish and Fisheries, 17, 483-506. http://dx.doi.org/10.1111/faf.12122

[35] Olesen, I., Gjedrem, T., Bentsen, H.B., Gjerde, B. and Rye, M. (2003) Breeding Programs for Sustainable Aquaculture. Journal of Applied Aquaculture, 13, 179-204. http://dx.doi.org/10.1300/J028v13n03_01

[36] Lind, C.E., Ponzoni, R.W., Nguyen, N.H. and Khaw, H.L. (2012) Selective Breeding in Fish and Conservation of Genetic Resources for Aquaculture. Reproduction in Domestic Animals, 47, 255-263. http://dx.doi.org/10.1111/j.1439-0531.2012.02084.x 